\title{
Implementasi Corporate Sosial Responsibility Perspektif Kearifan Lokal Dalam Meningkatkan Kinerja Lembaga Keuangan Mikro Traditional
}

\author{
I Nyoman Raditya Suparsabawa dan I Gede Sanica \\ Universitas Pendidikan Nasional Denpasar \\ E-mail: suparsabawa@gmail.com, gede_sanisca@yahoo.com \\ Diterima: Mei 2020; Dipublikasikan: Juli 2020
}

\begin{abstract}
ABSTRAK
Peneltian ini bertujuan untuk mengetahui implementasi CSR dalam perpektif kearifan lokal dalam meningkatkan kinerja LPD. Metodelogi yang digunakan dalam penelitian ini adalah metodelogi kualitatif. teknik pengumpulan dalam penelitian ini dilakukan dengan observasi, wawancara dan dokumentasi. Hasil penelitian menunjukan bahwa Informan dalam penelitian ini memandang bahwa CSR berlandaskan prinsip kearifan lokal Tri Hita Karana merupakan kewajiban sosial LPD untuk mensejahterkan dan mengaja ketahanan kearifan lokal. Praktik CSR berlandaskan Kearifan Lokal Tri Hita Karana telah di terapkan di LPD Desa Adat Tanjung Benoa. Relasi dengan masyarakat sangat dijaga sehingga masih dipercayai masyrakat sampai saat ini. Penganggaran Praktik CSR tetapkan dalam Rapat Desa dengan presentase sebesar $75 \%$ Dana CSR di kelola oleh Desa dan $25 \%$ dikelola oleh LPD Desa Adat Tanjung Benoa. Implementasi CSR berlandaskan kearifan lokal Tri Hita Karana memberikan kinerja yang meningkat baik secara berkesinambungan dari segi operasional maupun keuangan LPD Desa Adat Tanjung Benoa.
\end{abstract}

Kata Kunci: corporate social responsibility, kearifan local,kinerja LPD

\begin{abstract}
This research aims to knowing the implementation of CSR in the perspective of local wisdom in improving performance LPD. The methodology used in this study is a qualitative. collection techniques in this study were carried out by observation, interviews and documentation. The results showed that the informants in this study view that CSR is based on the principle of local wisdom Tri Hita Karana is a social obligation of the LPD to prosper and endure the resilience of local wisdom. CSR practices based on Tri Hita Karana's Local Wisdom have been applied in the Tanjung Benoa Indigenous Village LPD. Relationships with the community are maintained so that they are still trusted by the community to date. Budgeting of CSR practices is set at the Village Meeting with a percentage of $75 \%$ of the CSR Funds managed by the Village and $25 \%$ managed by the LPD of the Tanjung Benoa Indigenous Village. The implementation of CSR based on local wisdom Tri Hita Karana provides improved performance on an ongoing basis both in terms of operational and financial LPD Tanjung Benoa Indigenous Village.
\end{abstract}

Keywords: corporate social responsibility, local wisdom, performance LPD.

\section{PENDAHULUAN}

Masyarakat memiliki kearifan lokal (local wisdom) yang berbeda di setiap daerah, sehingga program-program tanggung jawab sosial perusahaan harus disesuaikan dengan kondisi masyarakat setempat tersebut. Hal tersebut sebagai konsekuensi keberadaannya perusahaan sebagai 'agent of development' di tengah-tengah masyarakat. Dengan demikian, sangat penting bagi perusahaan untuk mengetahui kondisi-kondisi sosial budaya masyarakat sekitar. Kegiatankegiatan tanggung jawab sosial (corporate social responsibility) perusahaan dengan demikian membutuhkan pemahaman yang baik dan mendalam mengenai kondisi masyarakat setempat dimana kegiatan corporate social responsibility (CSR) perusahaan tersebut diwujudkan.

Lembaga Perkreditan Desa (LPD) merupakan salah satu lembaga keuangan tradisional mikro di Bali yang didirikan oleh Desa Adat dimana memiliki fungsi untuk wadah investasi Desa Adat dan sebagai pengawas perekonomian masyarakat Desa. Selain itu juga, LPD mengelola sumber daya keuangan dan investasi jangka panjang milik Desa Adat yaitu dalam bentuk simpan pinjam, untuk keperluan pembiayaan kehidupan anggota masyarakat Desa Adat, baik secara Individui maupun secara Kelompok, dalam rangka pengembangan fungsi-fungsi sosio-kultural dan keagamaan masyarakat Desa Adat. Dari hasil penelitian terdahulu Dwinta (2016) yang meneliti tentang LPD menjelaskan bahwa LPD sebagai lembaga keuangan mikro 
tradisional sangat menekankan pada kuatnyasuatu budaya organisasi berbasiskan kearifan lokal dalam lingkungan kerja dimasing-masing LPD guna menciptakan suatu pola kerja yang harmonis yang kemudian di praktikan dalam bentuk prilaku dalam melayani nasabah. Tanggung jawab sosial perusahaan atau corporate social responsibility (CSR) merupakan sebuah gagasan yang menjadikan perusahaan tidak lagi dihadapkan pada tanggung jawab yang berpijak pada single bottom line, yaitu nilai perusahaan (corporate value) yang direfleksikan dalam kondisi keuangannya (financial) saja. Tapi tanggung jawab perusahaan harus berpijak pada triple bottom lines yaitu juga memperhatikan masalah sosial dan lingkungan (Daniri, 2017). Lebih lanjut ia mengungkapkan bahwa korporasi bukan lagi sebagai entitas yang hanya mementingkan dirinya sendiri saja sehingga teralienasi atau mengasingkan diri dari lingkungan masyarakat di tempat mereka bekerja, melainkan sebuah entitas usaha yang wajib melakukan adaptasi kultural dengan lingkungan sosialnya. Corporate Social Responsibility (CSR) merupakan suatu konsep mengenai upaya yang dilakukan oleh lembaga atau perusahaan sebagai bentuk tanggung jawab terhadap stakeholders dan lingkungan sekitar di mana lembaga atau perusahaan itu berada. Segala kegiatan operasional yang di lakukan oleh perusahaan/lembaga sering kali menghasilkan dampak eskternal yang harus ditanggung oleh stakeholders dan lingkungannya. Dari pengertian diatas, wajar bila perusahaan/lembaga memperhatikan kepentingan dan nilai tambah bagi stakeholders maupun lingkungan sekitarnya.

Dalam lingkup luas Tri Hita Karana juga memliki konsep yang sama dengan CSR dalam menjaga suatu konsep yang berkesinambungan dalam memaksimalkan peran LPD di lingkungan masyarakat Purwati (2015). Dari uraian di atas dapat disimpulkan bahwa kedua konsep tersebut juga sangat relevan untuk diterapkan pada perusahaan jasa publik seperti Lembaga Keuangan Mikro (LKM) dan institusi publik lainnya baik yang berorientasi laba maupun nonlaba. Sebuah LKM yang merupakan organisasi bisnis yang berorientasi profit sudah barang tentu membutuhkan dana yang cukup guna melayani kebutuhan masyarakat dan membiayai semua aktivitas bisnisnya guna mencapai tujuan yang telah ditetapkan.

\section{TINJAUAN PUSTAKA}

Sejarah dan Praktik Corporate Social Responsibility (CSR) Perkembangan CSR dalam tinjauan sejarah, dapat ditemukan dalam Idowu (2011) disebutkan mengenai beberapa tahun yang memiliki momen penting dalam perkembangan CSR. Sejarah CSR dapat dilihat pula dari sudut pandang pengaruh media, Frank (2007) mengungkapkan tentang perkembangan CSR melalui sudut pandang Financial Times. Dalam tulisan itu disebutkan bahwa topik mengenai CSR sejak tahun 1984 sampai dengan tahun 2003 mengalami perkembangan yang sangat pesat terutama pada rentang tahun 1999 sampai dengan tahun 2003.

\section{Konsep Piramida CSR}

Konsep Piramida yang ada pada CSR di kembangkan oleh Archie B. Carrol yang memaparkan tentang empat tanggung jawab perusahaan, diantaranya :

1. Tanggung Jawab Ekonomis

Memiliki kata kunci make a profit. Dinyatakan bahwa tanggung jawab pertama perusahaan adalah menjadi unit ekonomi yang berfungsi dan mampu bertahan dalam usahanya Menurut Saidi (2004:59), motif utama perusahaan adalah menghasilkan laba. Laba adalah fondasi perusahaan. Perusahaan harus memiliki nilai tambah ekonomi sebagai persyaratan agar perusahaan dapat terus hidup (survive) dan berkembang.

2. Tanggung Jawab Etis

Memiliki kata kunci be ethical. Perusahaan memiliki kewajiban untuk menjalankan praktek bisnis yang baik, benar, adil dan fair. Norma-norma masyarakat perlu menjadi rujukan bagi perilaku organisasi perusahaan. (saidi 2004:56)

3. Tanggung Jawab Legal

Memiliki kata kunci obey the law. Tanggung jawab hukum perusahaan menuntut agar bisnis yang dilakukan mematuhi hukum "bermain dalam aturan main". Hukum dipahami sebagai pandangan moral masyarakat yang dikondisifikasikan dank arena itu mematuhi standarstandar ini merupakan prasyarat lebih lanjut mengenai tanggung jawab social 


\section{Tanggung Jawab Filantropis}

Memiliki kata kunci be a good citizen. Selain itu perusahaan harus memperoleh laba, taat hukum dan berperilaku etis, perusahaan dituntut agar dapat memberi kontribusi yang dapat dirasakan secara langsung oleh masyarakat. Tujuannya adalah untuk meningkatkan kualitas kehidupan semua. Para pemilik dan pegawai yang bekerja di perusahaan memiliki tanggung jawab ganda, yakni kepada perusahaan dan kepada publik yang kini dikenal dengan istilah non-fiduciary responsibility (Saidi, 2004:60)

\section{Konsep CSR Triple Bottom Line}

Konsep Piramida yang dikenalkan oleh Archie B. Carrol CSR juga didasari oleh tiga prinsip dasar tentang kepedulian sosial yang disebut dengan Triple Bottom Line oleh John Elkington (1998). Berikut ini merupakan bagian dari prinsip-prinsip Triple Bottom Line menurut John Elkington :

\section{Profit}

Perusahaan tetap harus berorientasi untuk mencari keuntungan ekonomi yang memungkinkan untuk terus beroperasi dan berkembang. Menurut Ermy dan Supartha (2015:2), Profit meliputi kinerja keuangan perusahaan arus modal dan ketelirbatan ekonomi mereka dalam masyarakat. CSR harus menjamin bahwa perusahaan bertanggung jawab atas dampak langsung dan tidak langsung dari kegiatan mereka.

2. People

People meliputi dampak perusahaan pada karyawan dan system sosial dalam masyarakat (Emmy dan Supartha, 2015:2). Perusahaan harus memiliki kepedulian terhadap kesejahteraan manusia. Beberapa perusahaan mengembangkan CSR, misalnya pemberiaan program beasiswa untuk pelajar, pendirian sarana pendidikan, pendirian tempat ibadah, berkontribusi dalam bidang kesehatan hingga pada perlindungan bagi masyarakat setempat (Rachmat, 2014).

3. Planet

Perusahaan peduli terhadap lingkungan hidup dan berkelanjutan keragaman hayati. Beberapa program CSR yang berpijak pada prinsip ini biasanya berupa penghijauan lingkungan hidup, penyediaan sarana air bersih, perbaikan pemukiman hingga pengembangan pariwisata (Rachmat, 2014).

\section{Penerapan Corporate Social Responsibility}

Penerapan Corporate Social Responsibility (CSR) membutuhkan ilkim organisasi yang saling percaya dan kondusif, sehingga memunculkan motivasi dan komitmen karyawan pelaksana (Nor Hadi, 2011:142), Menurut Fitalina (2013:25), pelaksanaan tanggung jawab sosial yang harus dilaksanakan oleh suatu perusahaan menuntut diberlakukan etika bisnis, perusahaan yang tidak memperhatikan kepentingan umum dan kemudian menimbulkan gagasan lingkungan akan dianggap sebagai bisnis yang tidak etis.

\section{Kearifan Lokal Tri Hita Karana}

Konsep kearifan lokal Tri Hita Karana menurut (Wiana: 2004) merupakan falsafah hidup tangguh. Falsafah tersebut memiliki konsep yang dapat melestarikan keanekaragaman budaya dan lingkungan di tengah hantaman globalisasi dan homogenisasi. Sebuah falsafah kultur Bali Tri Hita Karana yang menekankan pada teori keseimbangan menyatakan bahwa masyarakat Hindu cenderung memandang diri dan lingkungannya sebagai suatu sistem yang dikendalikan oleh nilai keseimbangan dan diwujudkan dalam bentuk prilaku. Tri Hita Karana, secara etimologi terbentuk dari kata : tri yang berarti tiga, hita berarti kebahagiaan, dan karana yang berarti sebab atau yang menyebabkan, dapat dimaknai sebagai tiga hubungan yang harmonis yang menyebabkan kebahagian. Prinsip pelaksanaannya harus seimbang, selaras antara satu dan lainnya. Apabila keseimbangan tercapai, manusia akan hidup dengan mengekang dari pada segala tindakan berekses buruk. Hidupnya akan seimbang, tenteram, dan damai. Hubungan antara manusia dengan alam lingkungan perlu terjalin secara harmonis, bilamana keharmonisan tersebut di rusak oleh tangan- tangan jahil, bukan mustahil alam akan 
murka dan memusuhinya. Jangan salahkan bilamana terjadi musibah, kalau ulah manusia suka merusak alam lingkungan. Tidak disadari bahwa alam lingkungan telah memberikan kebebasan kepada manusia untuk dimanfaatkan sebesar-besarnya guna kesejahteraan hidupnya. Penjelasan lainya mengenai Hakikat mendasar Tri Hita Karana juga dikemukakan oleh (Wiana: 2004) Hakikat mendasar Tri Hita Karana mengandung pengertian tiga penyebab kesejahteraan itu bersumber pada keharmonisan hubungan antara manusia dengan Tuhan nya, manusia dengan alam lingkungannya, dan manusia dengan sesamanya. Dengan menerapkan falsafah tersebut diharapkan dapat menggantikan pandangan hidup modern yang lebih mengedepankan

Prisnip Hubungan Harmonis antara Manusia dengan Tuhan. Dalam awal penciptaannya Manusia merupakan makhluk yang diberi derajat paling tinggi oleh Tuhan diantara ciptaannya yang lain dalam kelahirannya di bumi manusia dibekali Tri Pramana sabda (suara), bayu (tenaga), idep (pikiran). ketiganya unsur tersebut berjalan dengan seimbang dan saling mengendalikan satu sama lain untuk menjadikan karakter yang baik pada manusia tersebut. Maka, manusia semasa hidupnya dalam setiap pekerjaan dan kegiatannya selalu menggunakan ketiga unsur tersebut. Prinsip lain Hubungan Harmonis antara manusia dan tuhan juga didasari oleh konsep kaula (yang dikuasai) dan Gusti (yang menguasai).

Prisnip Hubungan Harmonis antara Manusia dengan Manusia didasari oleh implementasi ajaran Tri Kaya Parisudha, yakni ; Wacika (bertutur kata yang baik dan sopan), Kayika (berbuat sesuai ajaran dharma) dan manacika (selalu berfikiran positif) dengan menerapkan ajaran Tri Kaya Parisudha ini maka hubungan antar sesama dapat terciptanyasuasana ruku, harmonis dan damai serta saling membantu sama lain dengan hati yang penuh dengan cinta kasih yang mana kasih merupakan dasar kebajikan. Kasih muncul dari dalam kalbu yang merupakan alam paramatman, yaitu lama ananda (kebahagiaan).

Prinsip Hubungan Harmonis antara Manusia dengan Lingkungan. Manusia dalam kehidupannya di bumi ini memerlukan ketentraman, kesejukan, ketenangan dan kebahagiaan lahir bhatin. Untuk mencapai tujuan tersebut manusia tidak bisa hidup tanpa adanya bhuana agung (alam semesta). Manusia hidup dialam dan dari hasil alam. Filosofi lain hubungan manusia dan lingkungan (alam semesta) dikembangkan dalam perumpamaan janin dalam Rahim, dalam hal ini manusia adalah janin dan alam adalah rahim. Manusia akan tumbuh dan berkembang didalam lingkungan alam semesta sebagai kesatuan dari unsur Tri Hita Karana. Jika manusia merusak alam, maka dia sendirilah yang terlebih dahulu akan musnah (hukum alam).

\section{Lembaga Perkreditan Desa}

Pembentukan LPD dilator belakangi oleh keterbatasan modal dan permodalan yang dimiliki oleh karma Desa Pakraman yang dapat menjangkau kredit-kredit yang dibutuhkan masyarakat untuk menjalankan usahanya. LPD sejak digagasnya pada bulan November 1984 oleh Gubernur Bali, yang pada waktu itu di jabat oleh Prof. Ida Bagus Mantra (alm), LPD telag mengemban fungsi mendorong pembangunan ekonomi masyarakat melalui tabungan yang terarah, serta menyalurkan modal yang efektif.

LPD didirikan oleh Gubernur Bali Prof. Ida Bagus Mantra pada tahun 1985, sebagai lembaga keuangan pedesaan berbasis Desa Adat. Dimana LPD memiliki peran ekonomi dan sosial dikomunitas tersebut. Modal awalnya merupakan hibah dari gubernur sebesar Rp. 2,5 juta pada setiap LPD di Bali. Keanggotaan berdasarkan "Banjar" dan Desa Pakraman, merupakan unit terpenting dari organisasi sosial di masyarakat Bali (Sutoro, 2015:16). LPD dibentuk berdasarkan pada keputusan Gubenur Bali Nomor 972 Tahun 1984 tentang pembentukan Lembaga Perkreditan Desa di Bali. Sk Gubernur diperkuat dengan peraturan No 8 tahun 2002 dan Peraturan Nomor 3 Tahun 2007 tentang Lembaga Perkreditan Desa hingga perubahan terakhir Peraturan No. 11 Tahun 2013 tentang LPD (Anatawikrama, 2013). Menurut Peraturan Daerah Provinsi Bali Nomor 3 Tahun 2017 Tentang Lembaga Perkreditan Desa Lembaga Perkreditan Desa yang selanjutnya disebut LPD adalah lembaga keuangan milik Desa Pakraman yang berkedudukan di wewidangan Desa Pakraman. Dimana dalam operasionalnya LPD juga diawasi oleh Lembaga Pemberdayaan Lembaga Perkreditan Desa, selanjutnya disebut LPLPD adalah suatu lembaga yang berfungsi melaksanakan pemberdayaan LPD. LPD merupakan 
lembaga keuangan milik Desa Pakraman yang telah berkembang dan memberikan manfaat sosial, ekonomi, budaya pada anggotanya. Dengan demikian, LPD harus dibina dan ditingkatkan kinerjanya untuk pencapaian penigngkatan taraf hidup msayarakat Desa. LPD juga dinyatakan sebagai wadah asset Desa yang dimiliki oleh warga adat (Damayanthi, 2015:10). Lapangan usaha LPD mencangkup menerima dan menghimpun dana dari karma desa dalam bentuk keuangan dan deposito, memberikan pinjaman hanya kepada karma desa dan menerima pinjaman dari lembaga-lembaga keuangan maksimum sebesar $100 \%$ dari jumlah modal, termasuk cadangan dan laba ditahan kecuali batasan lainnya dalam jumlah pinjaman atau dukungan/bantuan dana (Sukandia, 2011:36). LPD memiliki tujuan untuk membantu masyarakat Desa dalam aspek permodalan untuk dikembangkan guna meningkatkan usaha ekonomi masyarakat Desa. Kegiatan operasional LPD memiliki tujuan yaitu tujuan jangka pendek dan jangka panjang. Tujuan jangka pendek LPD adalah untuk memperoleh laba yang maksimal sedangkan tujuan jangka panjang LPD adalah untuk mempertahankan kontinuitas usahanya (Cahyadi, 2014:2).

\section{Sejarah Lembaga Perkreditan Desa (LPD Tanjung Benoa}

Lembaga Perkreditan Desa (LPD) Desa Adat Tanjung Benoa berdiri sejak Tanggal 20 Mei 1990, berdasarkan Keputusan Gubernur Kepala Daerah Tingkat I Bali Nomer 36 Tahun 1990. Bendesa Adat Tanjung Benoa saat itu adalah I Nyoman Wana Putra, BA. Pada awal berdirinya LPD Desa Adat Tanjung Benoa dengan modal awal yaitu sebesar Rp 4,6 Juta. Modal ini bersumber dari Rp 2 Juta bantuan Pemerintah Daerah (Pemda) Tingkat I Bali, dan Rp 2,6 juta dari Pemda tingkat II Badung. Pada saat itu yang mengelola LPD dalam operasionalnya terdiri dari : I Made Djartha selaku ketua, Ni Luh Raka Wiratna sebagai Sekretaris dan Ni Nyoman Respini sebagai Bendahara serta Dahlia sebagai pengelola dana. Sejalan perkembangan LPD pada saat ini sudah memiliki karyawan 19 orang dan 1 Ketua Badan Pengawas yang dibantu oleh 4 orang anggota Badan Pengawas. LPD diatur berdasarkan Peraturan Daerah Provinsi Tingkat I Bali Nomor 2 Tahun 1988 yang telah diganti dengan Peraturan Daerah Provinsi Bali Nomor 8 Tahun 2002 Peraturan Perubahan Nomer 3 Tahun 2007 tentang Lembaga Perkreditan Desa. Dengan adanya pelaksanaan otonomi daerah kini Kabupaten Badung juga memiliki Perda Tentang LPD yakni Peraturan Kabupaten Badung Nomer 19 Tahun 2001 Tentang Lembaga Perkreditan Desa di Kanupaten Badung. LPD Desa Adat Tanjung Benoa dalam operasionalnya tidak hanya melayani masyarakat Desa Adat akan tetapi juga melayani penduduk pedatang berdomisili di Desa Adat Tanjung Benoa.

Desa Adat Tanjung Benoa berada di Kecamatan Kuta Selatan, Kabupaten Badung (Bali Selatan) dengan potensi luas wilayah Desa Adat Tanjung Benoa yang terbagi menjadi 4 banjar Adat dengan Jumlah Penduduk 4.613 Jiwa dan $1.042 \mathrm{KK}$, dengan sumber daya yang ada seperti alam pesisir pantai dan industri pariwisata seperti Water Sport, Hotels, Restaurant dan perdagangan. (Sumber : BPO LPD Desa Adat Tanjung Benoa 2019).

\section{METODE PENELITIAN}

Metodelogi yang digunakan dalam penelitian ini adalah metodelogi kualitatif. Menurut Flick dalam Gunawan (2014:81) penelitian kualitatif adalah keterkaitan spesifik pada studi hubungan sosial yang berhubungan dengan fakta dari pluralisasi dunia kehidupan. Metode ini diterapkan untuk melihat dan memahami subjek dan obyek penelitian yang meliputi orang, lembaga berdasarkan fakta yang tampil secara apa adanya. Melalui pendekatan ini akan terungkap gambaran mengenai aktualisasi, realitas sosial, dan persepsi sasaran sosial. Tujuan penelitian kualitatif adalah menggambarkan dan mengungkap (to descrie and explore), dan menggambarkan dan menjelaskan (to describe dan explain). Kebanyakan penelitian kualitatif bersifat deskriptif dan eksplanatori. Penelitian kualitatif (Qualitative research) adalah suatu penelitian yang ditujukan untuk mendeskripsikan dan menganalisis fenomena, peristiwa, aktivitas sosial, sikap, kepercayaan, persepsi, pemikiran orang secara individu maupun kelompok.

Lokasi penelitian merupakan tempat dimana peneliti akan melakukan penelitiannya, terutama dalam menangkap fenomena atau peristiwa yang sebenarnya terjadi dari objek yang 
diteliti dalam rangka mendapatkan data-data penelitian yang tepat dan akurat. Adapun lokasi diambil dalam penelitian ini yaitu Lembaga Perkreditan Desa (LPD) di LPD Desa Adat Tanjung Benoa, Kecamatan Kuta Selatan, Kab. Badung, Bali.

Teknik pengumpulan data merupakan langkah yang paling utama dalam penelitian, karena tujuan utama dari penelitian adalah mendapatkan data. menurut (Sugiyono, 2016) bila dilihat dari segi cara atau teknik pengumpulan data, maka teknik pengumpulan data dapat dilakukan dengan observasi, wawancara dan dokumentasi. Namun dalam penelitian ini teknik pengumpulan data yang dilakukan oleh peneliti adalah dengan melalui tiga metode, yaitu: Observasi, Wawancara, Dokumentasi.

Dalam penelitian kualitatif biasanya tidak menggunakan populasi, karena penelitian yang menggunakan kualitatif berangkat dari kasus tertentu yang ada pada situasi sosial tertentu dan hasil kajiannya tidak akan diberlakukan pada populasi, tetapi dapat menjadi suatu pertimbangan ke tempat lain pada situasi sosial dalam kasus yang dipelajari. Sampel dalam penelitian kualitatif tidak disebut responden melainkan narasumber, partisipan atau informan (Sugiyono : 2016).Penentuan informan diambil untuk mendapatkan informasi dari pihak manajemen dan kepegawaian. Maka, pemilihan informan dilakukan dengan menggunakan teknik sample bertujuan (purposive sample) dengan jenis secara subjektif. Informan dalam penelitian ini diuraikan sebagai berikut:

Informan dalam tahap wawancara semistruktur berdasarkan atas informasi yang ingin didapatkan dari bagian manajemen. Informan dalam tahap ini adalah sebagai berikut:

1. Ketua LPD Desa Adat Tanjung Benoa.

2. Badan Pengawas LPD Desa Adat Tanjung Benoa.

3. Struktural Inti Pengurus LPD Desa Adat Tanjung Benoa.

Agar dapat dipertanggungjawabkan, data-data yang diperoleh perlu terlebih dahulu dengan menguji keabsahan data. Teknik pemeriksaan keabsahan data (validitas data) dalam penelitian ini adalah teknik triangulasi. Teknik triangulasi menurut Sugiyono (2016:327) menyatakan bahwa teknik triangulasi merupakan teknik pengumpulan data data dan sumber yang telah ada. Bila penelitian melakukan pengumpulan data dengan triangulasi, maka sebenarnya peneliti mengumpulkan data yang sekaligus menguji kredibilitas data, yaitu mengecek kredibilitas data dengan berbagai teknik pengumpulan data dan berbagai sumber data. Dengan demikian peneliti melakukan pengumpulan berbagai data dengan sumber yang sama yaitu yang telah diperoleh dari melakukan pengumpulan data dari Lembaga Perkreditan Desa (LPD) Desa Adat Tanjung Benoa selanjutnya melakukan teknik data triangulasi sebagai langkah uji keabsahan data yang

Teknik analisis data yang digunakan dalam penelitian ini adalah analisis deskriptif kualitatif. Analisis kualitatif merupakan proses pencarian dan penyusunan data secara sistematis melalui pengamatan langsung di lapangan, wawancara, catatan lapangan dan bahan lainnya. Data tersebut dianalisis dengan cara mengorganisasikan data, menjabarkan dalam unit-unit, melakukan sintesa, menyusun ke dalam pola, memilih mana yang penting dan yang akan dipelajari, serta membuat kesimpulan yang dapat diceritakan kepada orang lain (Sugiyono : 2016). Aktivitas dalam menganalisis data kualitatif yaitu antara lain: 1) Pengumpulan Data (Data Collection), 2) Reduksi Data (Reduction Data), 3) Penyajian Data (Data Display), 4) Penarikan Kesimpulan (Concluting Drawing).

Data dapat dipercaya jika tidak ditemukan perbedaan atau tidak bertentangan dengan temuan penelitian maka data atau hasil yang didapatkan dalam penelitian dapat dinyatakan valid. Maka, dalam penelitian ini verivikasi keabsahan hasil analisis akan dilakukan dengan analisis deskriptif, yakni mendeskripsikan dan membandingkan data baik data wawancara, studi dokumentasi dan data hasil penyebaran kuesioner (Sugiyono, 2016).

\section{HASIL DAN PEMBAHASAN}

Berubahnya pandangan paradiga bisnis dari Single P (Profit) menjadi Triple Bottom Line (Profit, People, Planet). Istilah Triple Bottom Line dipopulerkan oleh Elington (1997) melalui bukunya Cannibals With Forks, Triple Bottom Line of Twentieth Century Business (Effendi, 2009). Konsep Triple Bottom Line menjelaskan bahwa perusahaan (Profit), Perusahaan juga bertanggungjawab untuk menjaga bumi (Planet) dan peduli dengan manusia 
(People) baik karyawan maupun masyarakat diluar perusahaan. Hal ini menunjukkan bahwa pengungkapan informasi oleh perusahaan tidak hanya sebatas satu aspek kinerja saja, melainkan keseluruhan indikator kinerja berkelanjutan (Sustainable Performance) yaitu kinerja ekonomi, sosial dan lingkungan (Maulida dan Adam, 2012).

LPD merupakan lembaga keuangan milik Desa Adat yang telah berkembang dan memberikan manfaat sosial, ekonomi dan budaya kepada masyarakatnya. Sebagai lembaga keuangan mikro milik Desa Adat di Bali, LPD menjalankan usahanya juga menekankan pada ajaran filosofi Tri Hita Karana yang mengacu pada menjaga hubungan harmonis dengan tuhan (parahyangan), hubungan harmonis antara manusia dengan sesamanya (pawongan), dan hubungan harmonis antara manusia dengan lingkungan (palemahan) Damayanthi, (2011). Selanjutnya menurut windia (2011) kalau investasi sudah dilakukan dan perusahaan sudah beroperasi, maka tujuan akhir dari bisnis itu adalah keberkelanjutan (Sustainability). Apabila suatu bisnis ingin berlanjut, maka bisnis itu seharusnya menerapkan hakikat konsep THK, yakni menerapkan konsep harmoni dan kebersamaan. Berdasarkan filosofi THK yang secara sadar dan nyata telah diterapkan oleh masyarakat di Bali, Maka LPD juga memiliki tanggung jawab pada masyarakat tempat LPD berdiri. Tanggung jawab sosial LPD meliputi tanggung jawab sosial yang berhubungan dengan filosofi THK. Sebaiknya untuk masa yang akan dating tanggung jawab sosial LPD dilaporkan dalam catatan laporan keuangan LPD atau laporan pertanggung jawaban sosial LPD.

Lembaga Perkreditan Desa (LPD) Desa Adat Tanjung Benoa berdiri sejak Tanggal 20 Mei 1990, berdasarkan Keputusan Gubernur Kepala Daerah Tingkat I Bali Nomer 36 Tahun 1990. Bendesa Adat Tanjung Benoa saat itu adalah I Nyoman Wana Putra, BA. Pada awal berdirinya LPD Desa Adat Tanjung Benoa dengan modal awal yaitu sebesar Rp 4,6 Juta. Modal ini bersumber dari Rp 2 Juta bantuan Pemerintah Daerah (Pemda) Tingkat I Bali, dan Rp 2,6 juta dari Pemda tingkat II Badung. Pengupayaan pelaksanaan praktik CSR dilakukan sejak berdirinya LPD Desa Adat Tanjung Benoa dengan dana seminim mungkin dan juga adanya PERDA yang mengikat mewajibkan untuk melakukan kegiatan CSR. Berikut ini respon Ketua LPD Desa Adat Tanjung Benoa sebagai infoman pertama yang peneliti tanyakan mengenai awal pengimplementasian praktik CSR:

"Nah kapan CSR itu dimulai sebenarnya dari LPD ini berdiri sudah terbentuklah CSR itu dalam arti karna di PERDA disebutkan $5 \%$ untuk dana Sosial nah sekarang cuman implementasi penerapannya kepada masyarakat dalam bentuk apa dikembalikan ke LPD masing-masing sesuai dengan keadaan dan situasi masyarakat dan sebagainya “

Peneliti dapat menyimpulkan bahwa disamping adanya PERDA yang mengatur untuk LPD melaksanakan praktik CSR upaya yang dilakukan LPD Desa Adat Tanjung Benoa dari awal berdirinya LPD ini sampai saat ini telah memberikan upaya kinerja yang berkesinambungan dengan berlandaskan konsisten dan inovasi yang terus dikembangan sehingga terciptanya hubungan yang selaras dengan masyarakat hingga sampai saat ini.

Pandangan Informan dalam penelitian ini memandang bahwa CSR berlandaskan prinsip kearifan lokal Tri Hita Karana merupakan kewajiban sosial LPD untuk mensejahterkan dan mengaja ketahanan kearifan lokal melalu kegiatan-kegiatan sosial yang tidak bertentangan dengan Konsep Triple Bottom Line dari Corporate Social Responsibility yaitu Profit, People, Planet dan konep kearifan Lokal Tri Hita Karana. Hasil Penelitian menunjukan bahwa bahwa CSR dan konsep Kearifan Lokal sangat berkaitan dimana konsep tersebut merupakan dasar bagi setiap kegiatan operasional yang dilakukan di lingkungan LPD Desa Adat Tanjung Benoa termasuk dalam pelaksanaan dalam CSR. Praktik CSR berlandaskan Kearifan Lokal Tri Hita Karana telah di terapkan di LPD Desa Adat Tanjung Benoa dari awal berdirinya LPD sampai saat ini dengan dana awal yaitu sebesar 4 juta sampai saat inimencapai 120 Juta. Implementasi praktik CSR yang dilakukan oleh LPD Desa Adat Tanjung Benoa tidak terlepas dari penjalinan relasi yang terjalin secara harmonis dengan masyarakat sekitar dan seluruh nasabah LPD sehingga implementasi praktik CSR benar-benar dirasakan sehingga membawa dampak bagi paragdima ditengah persaingan lembaga-lembaga keungan lainnya masyarakat untuk tetap memilih LPD sebagai wadah investasinya dan juga menjadi satu kesatuan yang saling berkaitan serta kesejahteraan masyarakat juga akan tercapai. penganggaran Praktik CSR berlandaskan 
filosofi Tri Hita Karana di LPD Desa Adat Tanjung Benoa di tetapkan dalam Rapat Desa (Paruman) dengan presentase sebesar $75 \%$ Dana CSR di kelola oleh Desa dan $25 \%$ dikelola oleh LPD Desa Adat Tanjung Benoa

Kearifan lokal merupakan salah satu motivasi dalam meningkatkan kinerja LPD Desa Adat Tanjung Benoa, dengan menerapkan Kearifan lokal yang diterapkan di sebuah lingkungan perusahaan menjadi salah satu pemberi motivasi atau bahkan semangat dalam peningkatan kinerja salah satu contohnya santunan untuk upacara keagaaman di Pura Desa, pemberian hadiah untuk nasabah, mengangkat sumber daya lokal generasi muda untuk regenerasi, pemberian tas ramah lingkungan untuk mengurangi penggunaan sampah plastik. Kearifan lokal yang diterapkan di sebuah perusahaan atau kantor berbeda-beda sesuai dengan situasi dan kondisi di lingkungan tersebut, seperti yang terjadi di LPD Desa Adat Tanjung Benoa. Penerapan kearifan lokal di LPD Desa Adat Tanjung Benoa dalam kaitannya untuk meningkatkan kinerja Lembaga Perkreditan Desa Sibetan ini dirasa sangat perlu. Hal ini terkait dalam pembayaran kredit salah satunya yang sudah dijelaskan tersebut, dengan pendekatan secara kekeluargaan ke pihak nasabah yang kreditnya macet akan memberikan keringanan kepada nasabah, karena dari pihak LPD tidak kaku pada aturan seperti aturan - aturan yang di terapkan di perbankan yang berpegang teguh pada aturan dalam pembayaran kredit.

LPD Desa Adat Tanjung Benoa memilki peranan yang baik di Desa Adat Tanjung Benoa, sampai saat ini LPD Desa Adat Tanjung Benoa sangat banyak nasabah yang meminjam modal untuk usaha (Hotel, Penginapan, Restaurant, Water Sport dll) dan juga kegiatan keagamaan. Para nasabah mempercayai LPD Desa Adat Tanjung Benoa sebagai tempat mendapatkan modal. Hal ini menjadikan LPD Desa Adat Tanjung Benoa sebagai salah satu LPD yang dikategorikan sehat di Kecamatan Kuta Selatan dilihat dari jumlah aset serta dana yang dimiliki oleh LPD Desa Adat Tanjung Benoa yang bersumber dari dana masyarakat dan yang bersumber dari pemberian kredit, deposito maupun tabungan.

Penelitian terdahulu Sila Prakarsa (2017), Cinthya Mustafa (2014), dan Gina Putri (2018) yang meneliti tentang Corporate Social Responsibility dan Kinerja Perusahaan memperoleh hasil bahwa pada perusahaan sektor pertambangan, manufactur dan perhotelan yang mengimplementasikan praktik CSR di masing-masing sektor tersebut memberikan dampak yang baik untuk kinerja perusahaan secara berkesinambungan (Sustainable Performance). Peran dari masing-masing prinsip Triple Bottom Line tersebut juga memberikan acuan sebagai dasar pelaksaan CSR sehingga saling berkaitan dengan konsep-konsep dasar lain nya dalam hal ini konsep kearifan lokal dimana kedua konsep tersebut saling melengkapi dan berjalan selaras untuk menghasilkan kinerja yang berkesinambungan (Sustainable Performance). Diluar dari penjabaran mengenai konsep Triple Bottom Line Hal yang tidak disampaikan dan dijelaskan dalam penelitian terdahulu peneliti mengembangkan hasil penelitian ini sehingga menjawab Konsep Piramida CSR yang kembangkan oleh Archie B. Carrol konsep ini merupakan konsep dasar untuk menunjang konsep Triple Bottom Line. Archie B. Carrol memaparkan tentang empat tanggung jawab perusahaan, diantaranya:

\section{1) Tanggung Jawab Ekonomis}

Motif utama perusahaan adalah menghasilkan laba. Laba adalah fondasi perusahaan. Perusahaan harus memiliki nilai tambah ekonomi sebagai persyaratan agar perusahaan dapat terus hidup (survive) dan berkembang. Berikut adalah kutipan hasil wawancara mendalam kepada Informan pertama yaitu Kepala LPD Desa Adat Tanjung Benoa yang berkaitan dengan laba yang menjadi tujuan utama dan kemudian didasari menjaga keharmonisan dengan unsurunsur kearifan lokal.

" LPD ini kan didirikan untuk mengajegkan Agama, Adat dan Budaya namun kembali lagi seperti yang saya katakan seseorang yang mendirikan suatu usaha goal jangka pendeknya adalah laba sedangkan jangka panjangnya adalah mensejahterakan pemegang saham dalam kaitan LPD yaitu masyarakatnya bagaimana masyarakatnya harus sejahtera harus kita bantu disamping ia bisa menikmati produk yang kita punya mereka juga harus kita fasilitasi atau kita berikan kegiatan sosial-sosial yang lain yang harus kita berikan bantuan juga. Nah hal tersebut merupakan salah satu treatment promosi jadi semakin dekat dengan customer atau masyarakat dan ketika masyarakat sudah dekat otomatis tidak pernah lepas dari kita di LPD artinya kita 
saling mengisi, LPD telah diisi oleh masyarakat degan menabung dan investasi dan bebrapa persen dari keuntungan patutnya kita juga isi dengan bantuan-bantuan sosial yang relevan untuk masyarakat"

Dengan adanya tanggung jawab ekonomis yang menjadi faktor pendorong utama LPD untuk meningkatkan kinerja yaitu memperoleh laba serta tak lepas dari keinginan memberikan pelayanan terbaik untuk nasabah dan masyarakat di Desa. Hal tersbut merupakan investasi yang harus dijaga untuk terciptanya sebuah keutuhan kerifan lokal, Dimana LPD sebagai lembaga keuangan tradisional yang hingga saat ini masih dipercaya masyarakat di Desa Adat Tanjung Benoa Sebagai wadah invetasinya.

\section{2) Tanggung Jawab Etis}

Memiliki kata kunci be ethical. Perusahaan memiliki kewajiban untuk menjalankan praktek bisnis yang baik, benar, adil dan fair. Norma-norma masyarakat perlu menjadi rujukan bagi perilaku organisasi perusahaan. Berikut adalah kutipan hasil wawancara mendalam kepada Informan pertama yaitu Kepala LPD Desa Adat Tanjung Benoa mengenai sikap dalam bekerja untuk ngayah di salah satu lembaga keuanga milik Desa Adat. "Sekarang Modal kita untuk bekerja adalah Jujur kalau itu lembaga keuangan dalam hal ini LPD mereka adalah kepercayaan karna unsur kepercayaan yang paling tinggi ketika nasabah sudah percaya maka ia akan berani menempatkan dana dalam bentuk tabungan maupun deposito. Kemudian LPD juga mempercayai jugan dengan pemakai uang-uang kita dalam bentuk kredit jadi disnin sangat penting adalah unsur kepercayan dan kejujuran. Karna dijaman sekarang dengan persaingan bank-bank umu, koperasi dll yang masuk kekuatan kita adalah kejujuran dan kepercayaan dengan mengelola uangnya dengan baik. Jika dilihat dari asset awal LPD mengelola 4 juta dan sekarang assetnya mencapai 230 Miliar jadi dengan demikian kepercayaan masyarakat semakin tinggi dan istilanya produk-produk LPD juga dinikmati " Dengan adanya komitmen yang kuat dalam internal LPD Desa Adat Tanjung Benoa untuk bekerja secara tulus ikhlas (Ngayah) merupakan cerminan dari landasan yang kuat yaitu kesatuan Kearifan Lokal sehingga menjadi tanggung jawab untuk mengemban tugas sebagai pegawai yang baik, benar, jujur dan adil.

\section{3) Tanggung Jawab Legal}

Memiliki kata kunci obey the law. Tanggung jawab hukum perusahaan menuntut agar bisnis yang dilakukan mematuhi hukum "bermain dalam aturan main". Hukum dipahami sebagai pandangan moral masyarakat yang dikondisifikasikan dank arena itu mematuhi standarstandar ini merupakan prasyarat lebih lanjut mengenai tanggung jawab social. Berikut adalah kutipan hasil wawancara mendalam kepada Informan pertama yaitu Kepala LPD Desa Adat Tanjung Benoa mengenai kepatuhan terhadap peraturan atau regulasi dari pemerintah

"Sangat wajib kita berpegangan dengan peraturan apalagi untuk kegiatan yang melibatkan kepentingan masyarakat banyak seperti CSR ini kembali lagi sesuai PERDA itu wajib cuman sekarang pendistribusiannya kita kondisikan dan koordinasikan dengan Bendesa Adat sesuai dengan anggara kegiatan dan dan yang sudah kita simpan “"

Agar teciptanya sebuah mekanisme yang terarah dan juga aman untuk kegiatan operasional yang melibatkan kepentingan masyarakat banyak LPD dalam melaksanakan praktik CSR ini sangat menaati regulasi yang berlaku dalam hal ini PERDA agar adanya tanggungjawab secara hukum yang harus ditaati apalagi kegiatan ini akan melibatkan banyak masyarakat.

\section{4) Tanggung Jawab Filantropis}

Memiliki kata kunci be a good citizen. Selain itu perusahaan harus memperoleh laba, taat hukum dan berperilaku etis, perusahaan dituntut agar dapat memberi kontribusi yang dapat dirasakan secara langsung oleh masyarakat. Berikut adalah rencana kerja dari LPD Desa Adat Tanjung Benoa sebagai salah satu media untuk wadah generasi muda di Desa agar memiliki peluang untuk bekerja di LPD Desa Adat Tanjung Benoa. "Selain itu juga kami selalu menyaring generasi pemuda-pemudi di Desa Adat lewat dana pembinaan kami setiap tahunnya tujuannya tentu untuk mengangkat potensi diri dan jiwa bekerja mereka semua untuk regenerasi. Kan setiap warisan kearifan lokal itu harus dan wajib ada yang meneruskan dan sinilah kami beri kesempatan untuk generasi muda dan sampai saat ini kami sudah mulai Open recruitment untuk calon pegawai-pegawai LPD saya rasa itu sangat dirasakan manfaatnya oleh masyarakat disini" 


\section{KESIMPULAN DAN SARAN}

Berdasarkan hasil uraian pembahasan di atas, peneliti menunjukan bahwa Implementasi CSR berlandaskan kearifan lokal Tri Hita Karana memberikan kinerja yang meningkat baik dari segi operasional maupun keuangan LPD Desa Adat Tanjung Benoa. Informan dalam penelitian ini memandang bahwa CSR berlandaskan prinsip kearifan lokal Tri Hita Karana merupakan kewajiban sosial LPD untuk mensejahterkan dan mengaja ketahanan kearifan lokal melalu kegiatan-kegiatan sosial yang tidak bertentangan dengan Konsep Triple Bottom Line dari Corporate Social Responsibility yaitu Profit, People, Planet dan konep kearifan Lokal Tri Hita Karana. Hasil Penelitian menunjukan bahwa bahwa CSR dan konsep Kearifan Lokal sangat berkaitan dimana konsep tersebut merupakan dasar bagi setiap kegiatan operasional yang dilakukan di lingkungan LPD Desa Adat Tanjung Benoa termasuk dalam pelaksanaan CSR. Praktik CSR berlandaskan Kearifan Lokal Tri Hita Karana telah di terapkan di LPD Desa Adat Tanjung Benoa dari awal berdirinya LPD sampai saat ini dengan dana awal yaitu sebesar 4 juta sampai saat inimencapai 120 Juta. Implementasi praktik CSR yang dilakukan oleh LPD Desa Adat Tanjung Benoa tidak terlepas dari penjalinan relasi yang terjalin secara harmonis dengan masyarakat sekitar dan seluruh nasabah LPD sehingga implementasi praktik CSR benar-benar dirasakan sehingga membawa dampak bagi paragdima ditengah persaingan lembaga-lembaga keungan lainnya masyarakat untuk tetap memilih LPD sebagai wadah investasinya dan juga menjadi satu kesatuan yang saling berkaitan serta kesejahteraan masyarakat juga akan tercapai. penganggaran Praktik CSR berlandaskan filosofi Tri Hita Karana di LPD Desa Adat Tanjung Benoa di tetapkan dalam Rapat Desa (Paruman) dengan presentase sebesar 75 \% Dana CSR di kelola oleh Desa dan $25 \%$ dikelola oleh LPD Desa Adat Tanjung Benoa.

Adapun saran yang dapat diberikan sebagai bahan pertimbangan evaluasi bagi perusahaan ialah sebagai berikut: Pelaksanaan praktik CSR berlandaskan konesp kearifan lokal Tri Hita Karana harus dilakukan secara berkesinambungan, sehingga dapat memberikan dampak positif bagi keberlangsungan hidup perusahaan di segala bidang dalam jangka pendek maupun jangka panjang, dan perlu adanya penyusunan strategi praktik CSR agar implementasi yang akan dilaksanakan dapat menghasilkan keuntungan atau kebermanfaatan nyata bagi perusahaan. Tidak hanya dalam bentuk materi, namun bisa dalam bentuk loyalitas nasabah ataupun masyarakat kepada LPD Desa Adat Tanjung Benoa.

\section{DAFTAR PUSTAKA}

Arifulsyah, Hamdani. (2016). Pengaruh Proporsi Kepemilikan Publik Terhadap Kinerja Keuangan Perusahaan, Dengan CSR Disclosure Sebagai Variabel Moderating. Jurnal Akuntansi Keuangan Dan Bisnis Vol. 9, November 2016, 58-67.

Dianti, Gina Putri. Mahyuni, Luh Putu. (2018). Praktik Corporate Social Responsibility (Csr) Pada Intercontinental Bali Resort Hotel: Eksplorasi Berbasis Pendekatan Filosofi Tri Hita Karana. Jurnal Ilmiah Akuntansi \& Bisnis Issn: 2528-2093 (Print), Issn: 2528-1216.

Erfina Kurnia Sari. (2011). "Pengaruh Kesempatan Pertumbuhan, Ukuran Perusahaan, dan Leverage Terhadap Kualitas Implementasi CG Pada Perusaaan Yang Terdaftar Di BEI Tahun 2006". Skripsi. Universitas Negeri Yogyakarta. Etty Murwaningsih. (2009). "Hubungan Corporate Governance, Corporate Social Responsibility dan Corporate Financial Performance Dalam Satu Continum. Jurnal Akuntansi Dan Keuangan. Vol. 11. No. 1. Mei. 2009: 30-41.

Etty Murwaningsih. (2009). "Hubungan Corporate Governance, Corporate Social Responsibility dan Corporate Financial Performance Dalam Satu Continum. Jurnal Akuntansi Dan Keuangan. Vol. 11. No. 1. Mei. 2009: 30-41.

Indra Sari, Auliyah P. P. (2016). Pengaruh Kinerja Keuangan Terhadap Nilai Perusahaan Dengan Pengungkapan CSR Dan GCG Sebagai Variabel Pemoderasi. e -Jurnal Riset ManajemenPRODI MANAJEMEN.

Jessica Risky Palinggi. (2011). "Pengaruh Jenis Industri Pada Luas Pengungkapa Tanggung Jawab Sosial Pada Laporan Tahunan Perusahaan (Studi Empiris Pada Perusahaan Yang Tercatat Di Bursa Efek Indonesia Tahun 2010). Skripsi. Universitas Hasanudin. 
Kartini, Dwi. (2013). Corporate Social Responsibility Transformasi Konsep Sustainability Management Dan Implementasi Di Indonesia. Bandung: PT Refika Aditama.

Kelana, Sinta Ayu , Ramdany. (2019). Pengaruh Pengungkapan Csr Terhadap Kinerja Keuanganis. PrPt. Asahimas Flat Glass Tbk. Jurnal Akuntansi, Vol. 8, No. 1, April (2019) P-Issn (2301-4075).

Kurniawan,Putu Sukma. (2016). Sintesa Unsur-Unsur Spiritualitas, Budaya, Dan Kearifan Lokal Masyarakat Bali Dalam Materi Kuliah Akuntansi Sosial Dan Lingkungan. Jurnal Pendidikan Akuntansi Indonesia, Vol. Xiv, No. 1, Tahun 2016.

Mai, Muhamad Umar. (2017). Mediation Of Csr And Profitability On The Influences Of Gcg Mechanisms To The Firm Value. Jurnal Keuangan Dan Perbankan, 21(2): 253-264, 2017.

Marten H. Jean, dkk, Corporate Social Responsibility Perusahaan Multinasional kepada Masyarakat Sekitar: Studi kasus, Jurnal Usahawan No. 3 tahun 2007, Bagian CSR Universitas Kristen Satya Wacana, Salatiga.

Novi Budiasni, Ni Wayan. (2016). Penerapan Corporate Social Responsibility pada Lembaga Keuangan Berbasis Kearifan Lokal. Jurnal Manajemen dan Bisnis. Volume 13, No. 2, September 2016, ISSN : 1829-8486.

Permana, Virgiawan Aditya. (2012). Pengaruh Kinerja Lingkungan dan Karakteristik Perusahaan terhadap CSR Disclosure (Studi Empiris pada Perusahaan Manufaktur yang terdaftar di BEI). Diponegoro Journal of Accounting, Volume 1 Nomor 2 Hal 1-12.

Prihatiningtias, YW. dan Dayanti, N. (2014). Corporate Social ResponsibilityDisclosure and Firm Financial Performane in Mining and Natural Resources Industry. The International Journal of Accounting and Business Society, 22 (1), pp: 35-58.

Prihatiningtias, YW. dan Dayanti, N. (2014). Corporate Social Responsibility Disclosure and Firm Financial Performane in Mining and Natural Resources Industry. The International Journal of Accounting and Business Society, 22 (1), pp: 35-58.

Prior, D., Surroca, J. dan Tribo, JA. 2008. Are Socially Responsible Managers Really Ethical? Exploring the Relationship Between Earnings Management and Corporate Social Responsibility. Corporate Governance: an international Review, 16 (3), pp: 160-177.

Purwati, Indah. (2013) Corporate Social Responsibility Berlandaskan Filosofi Tri Hita Karana Pada Lembaga Perkreditan Desa (Studi kasus LPD Desa Adat Kuta). Bali : Universitas Udayana.

Rawi dan Munawar Muchlish. (2010). "Kepemilikan Manajemen, Kepemilikan Institusi, Leverage, dan Corporate Social Responsibility". Simposium Nasional Akuntansi XIII. AKPM_23.

Rawi dan Munawar Muchlish. (2010). "Kepemilikan Manajemen, Kepemilikan Institusi, Leverage, dan Corporate Social Responsibility". Simposium Nasional Akuntansi XIII. AKPM_23.

Sari, Dwinta. (2016) Dampak Corporate Social Responsibility (CSR) Lembaga Perkreditan Desa (LPD) Terhadap Pemberdayaan Masyarakat Desa Adat Gulingan, Kecamatan Mengwi, Kabupaten Badung. Bali : Universitas Udayana.

Sri Purnami, Anak Agung. (2019). Strategi Pengembangan CSR LPD dalam Upaya Penguatan Implementasi Tri Hita Karana dan Kesejahteraan Masyarakat (Studi Pada LPD di Kecamatan Kintamani). Wacana Ekonomi (Jurnal Ekonomi, Bisnis dan Akuntansi) Volume 18, Nomor 2, 2019; pp. 75-81.

Sri Rahayu. (2010). "Pengaruh Kinerja Keuangan Terhadap Nilai Perusahaan Dengan Pengungkapan Corporate Social Responsibility Dan Good Corporate Governance Sebagai Variabel Moderasi (Studi Empiris Pada Perusahaan Manufaktur di Bursa Efek Jakarta)". Skripsi. FE. Universitas Diponegoro.

Sugiyono. (2014). Metode Penelitian Kuantitatif, Kualitatif, dan R\&D. Bandung: Alfabeta. Sugiyono. (2016). Metode Penelitian Kuantitatif, Kualitatif, dan R\&D. Bandung: Alfabeta. Windari, Ratna Artha. Yuliartini, Ni Putu Rai. (2018). Penerapan Tanggung Jawab Sosial Perusahaan Berbasis Kearifan Lokal di Pabrik Kata-Kata Joger Tabanan. Seminar Nasional Riset Inovatif 2018 ISBN 978-602-6428-73-8. 